\title{
Diaspora and development
}

\section{Ben Page and Claire Mercer}

\section{Introduction}

There are few areas of public policy in which the idea of a diaspora has been applied more instrumentally and extensively than in the international development sector. A cursory perusal of Developing a road map for engaging diasporas in development: a handbook for policymakers and practitioners in home and host countries, published in 2012 by the International Organization for Migration (IOM) and the Migration Policy Institute (MPI), reveals the current thinking. The task of governments in the Global South is to get to know their diaspora, to mobilize it and to build the diaspora's capacity to contribute to homeland development. In some cases the task is even to construct a diaspora if none exists. In this policy-framing diasporas are a source of remittances to be leveraged, investment to be procured and human capital to be returned. Engage your diaspora to boost your economic growth (Mithra, 2016)! This is a topic where the definition of 'diaspora' is a long way from the standard academic definitions that have been used in the past. From the global development industry's perspective, first generation migrants form the primary group of 'diasporas' with whom they attempt to engage, though any individual can be enrolled as long as they are (or can be encouraged to be) sympathetic to the development of their ancestral homeland.

In this chapter we start by describing how diaspora has been applied to development practice since the 1990s. We show how the global development industry is attempting to incorporate diasporas into mainstream development interventions, just as it has done in the past with gender, participation or civil society. To do this we distinguish between the activities of the governments of diaspora-home countries, the World Bank's remittances team, other development industry actors and the governments of diaspora-hosting countries. This typology is problematic because of the home/host distinction and because it suggests separation where there is often connection, co-operation and overlap. It also deliberately ignores individuals in diasporas themselves, except when they explicitly organise as development-diaspora NGOs. We then provide a more critical analysis of four conceptual terrains where diaspora and development have been brought together: modernization, time/space, belonging/identity and securitization/financialization.

\section{How have diaspora and development been brought together in practice?}

The governments of diaspora-sending countries in the Global South are seen as the key actors in this field. They are being encouraged to follow a 'road map' in order to solicit the help of 'their diaspora' for national development (IOM and MPI 2012). Since the turn of the millennium many of these governments have opened diaspora ministries and sub-ministries (Kleist and Turner, 2013, Gamlen, 2014). The menu of activities they undertake includes identifying and mapping the diaspora; building trust with the diaspora through initiatives such as 
extending dual citizenship, holding cultural events and providing services to those abroad; and finally incentivising individuals in the diaspora to invest in their homeland through information centres, tax breaks, 'diaspora days' and other policy fora. The hope is that, as a result, members of the diaspora will invest both financial and human capital in their countries of origin. This might mean setting up new businesses, or (for the highly skilled) coming home to work on a temporary or permanent basis. Another approach, focuses not on entrepreneurs in the diaspora but on diaspora groups with an appetite for philanthropy. This was pioneered by the Mexican government's Tres Por Uno programme, which provides matching development funding for diaspora organizations from federal, state and municipal governments (Lopez 2015). These projects have typically been small-scale hometown investments in public goods such as potable water and electrification.

The World Bank's Migration and Remittance Team is also a major player shaping diaspora and development activities in diaspora-sending and diaspora-receiving countries (Ratha and Plaza, 2016). Their key interventions seek to maximise formal remittances to developing countries based on the belief that such capital is a major contributor to economic growth in the Global South. This is achieved through four principal routes. First, they disseminate data, knowledge and research on remittances and on their development impacts. Much of this information is made available through the Global Knowledge Partnership on Migration and Development (KNOMAD), funded by the Bank and the Governments of Germany, Switzerland and Sweden. Second, the World Bank provides funding for technical assistance and advisory services to governments that are developing diaspora policies in order to maximise benefits and minimise risks associated with migration. Third, the Bank is at the forefront of attempts to reduce the cost of sending remittances around the world. Finally, the Bank, along with others, has argued for the leveraging of remittances for development by introducing financial products aimed at the diaspora, such as diaspora bonds.

In addition to the above actors, there are a group of institutions that, taken together, constitute that part of the global development industry that is explicitly focused on international migration and diaspora. These include other multilateral development agencies (such as IOM and Global Forum on Migration and Development), NGOs (such as AFFORD), thinktanks (such as Migration Policy Institute) and migrant lobby groups (such as Migrants' Rights Network). These have been active in a range of migrant issues including: migrant workers' rights, remittance costs and the impact of brain drain. They have most recently organized around getting diaspora-related issues recognized in the 2015 Sustainable Development Goals.

The actors not yet discussed are the governments in diaspora-receiving states. This was the institutional site of many early experiments linking diasporas to international development, such as the co-development policies of Spain, Italy and France in the 1990s (which mostly linked funding from development budgets to return migration). Ultimately, however, many of these interventions are relatively limited in scope. For example, the key diaspora project for the Department for International Development in the UK, the Common Ground Initiative, has amounted to only $£ 32$ million of funding for African diaspora 
organizations over 10 years. This initiative provides direct project grants as well as money for capacity building and research. In the recent past there has been interest in 'mapping' various diaspora communities within the UK, but less of an idea about how to engage these communities in the development of their place of origin. Since 2016 diaspora issues seem to have slipped down DFID's agenda in the UK and, at the time of writing, there is no explicit diaspora-development policy listed on their website at all.

\section{How have diaspora and development been brought together conceptually?}

So far we have described the institutions and activities of the international development industry in relation to the ambition to enrol diasporas in development. In this section we shift away from what such actors are attempting to do in a top-down manner, to identifying, and critiquing, the concepts underpinning these diaspora and development initiatives.

First are the traces of the colonial dimension embedded within the concept of modernization, which echo through the diaspora-development field. For example, the Global North is often imagined as the location of more 'developed' values, such as being pro-democracy and gender equality. Diaspora communities, it is implied, absorb these values through a process of social osmosis from the locales in which they now live. The implicit hierarchy in development's reading of 'modernization' justifies a conception of diasporans remitting these more advanced values to their backward homeland through their transnational linkages. However hard more sophisticated theorizations of social remittances seek to emphasize the bi-directional movement of values and the dynamic hybrid qualities of transnational cultures (Levitt and Lamba-Nieves, 2011), the idea that modern values move from North to South when migrants return persists in development practice because of the way in which 'development' is imaginatively wedded to those colonial cultural hierarchies. Empirical examples that emphasize the more complex pathways taken by values when people move (for example JoAnn McGregor's (2008) work on 'African values' in relation to children and education among transnational Zimbabwean families) are problematic for conceptualizations that see diasporas as carriers of modern values. In practice such examples must either be sidelined by those who build the road maps of diaspora engagement or explained away through the ideological mechanisms of orientalism, which can present African values as the stubbornly persistent quirks of essentialized exotic 'traditional' cultures.

Further, there is also an untroubled confidence in much diaspora-development policy about what modernization looks like and how it will be delivered. In this context development is defined as 'what development professionals trained in the Global North do', and it is distinctly not what non-professionals in the diaspora might imagine it to be (Sinatti and Horst 2014). Of course there is much overlap in how development professionals and diasporans think of development, but there are also important areas of divergence, for example around what kinds of projects might count as 'modernization'. In our own research with African hometown associations we have encountered diasporas' energies being channelled into local improvements in the hometown such as refurbishing a mortuary, pursuing land disputes and erecting cultural monuments. These 
activities were clearly understood by the diaspora as 'developmental' but would not usually find support in development programming by development professionals (Mercer et al 2008). Assumptions about what counts as the 'productive' uses of remittances are equally problematic, with many of the everyday uses of diasporans' remittances dismissed as unproductive when set against an index of capitalist business. House-building is a good example since it accounts for a large proportion of the money sent home by diasporas, yet such spending is often considered unproductive and even inflationary (despite the fact that house-building has significant local economic effects including the purchase of materials and labour) because it is fundamentally a form of consumption. For those people building these 'modern' houses, however, their projects are unambiguously developmental.

The second set of concepts where diaspora and development meet are those associated with space and time. In development studies the geography of diaspora is often imagined as a series of ahistorical binaries such as North/South, developed/developing, host/home, sending/receiving and here/there (Raghuram 2009), which are currently traversed by migrants in order to produce diasporas and then remittances (Datta, 2009). As Raghuram (2009, p113) points out, what is missing from this framework is any understanding of the historical "co-constitution of Europe and the colonies", which was not only central to producing current patterns of inequality but which has also meant that "the spaces for/of development are already mixed up, that migrants 'here' might need development, and that migrants 'there' might be agents of development "here'” (ibid).

The mixing up of the spaces of development has a long temporal trajectory. For example the work of Judith Carney (1993) has shown that rice cultivation along the American Atlantic Coast from the mid-18 ${ }^{\text {th }}$ century was dependent upon the understanding of rice farming among the West African slave diaspora. Although this contribution to the economic development of the American South has been largely ignored or actively denied, Carney argues that, "before the outbreak of the Civil War, an estimated 100,000 slaves were planting between 168,000 and 187,000 acres of wetland rice. The antebellum rice economy included the richest planters of the U.S. South, and the region's capital, Charleston, gloried in one of the greatest concentrations of wealth in the world" (Carney 1993, 78). This 'development' located in the USA was built not just on diaspora labour, but also on diaspora knowledge. Similarly, the massive transfer of capital from the slave plantations of the Caribbean to the urban infrastructure of Britain in the late $18^{\text {th }}$ and early $19^{\text {th }}$ centuries, illustrates that the industrial revolution and the development that ensued was not so much an illustration of Britain's national genius as a product of forced global population movements. Nor, as Giles Mohan (2002) pointed out long ago, is this process only historical. The development of $21^{\text {st }}$ century Britain is a product of immigration - with new capitalist enterprises, which would not otherwise exist, emerging to serve diaspora populations - as well as of the emigration of the $21^{\text {st }}$ century diaspora of British citizens around the world (MacRae and Wright, 2006). American and British development was, and is, co-constituted by its diasporas. 
The third conceptual framework where diaspora encounters development circulates around the ideas of belonging and autochthony. Whilst these ideas have historically been core to debates in diaspora studies, they have been less central in development theory. One of the consequences of connecting development to diaspora has been to give more prominence to these ideas in development studies. This is most easily illustrated through what Oliver Bakewell has described as the 'sedentary bias' (2008) that pervades much of the diaspora and development field and assumes that mobility in and of itself is an aberration because people really belong at 'home' (de Haas 2007). The idea of belonging is used in multiple ways that have fairly unsubtle policy aspirations with obviously political overtones. For example attempts to use development as a means to eventually stop migration from the Global South to the Global North (de Haas 2007) or as attempts by governments of the Global South to use appeals to patriotism to repatriate capital from their diasporas back to where it belongs at home. In both cases the idea is that all people really belong in some local home. People's affection for their homes becomes both a resource to be used in the effective management of national development and a moral justification for trying to manage who lives where in the world by those who seek to restrict movement.

The sedentary bias is rooted in essentialist understandings of identity which privilege a place of origin, usually a birthplace, as an unchanging home to which diasporas will always be oriented. Indeed, Sinatti and Horst $(2014,137)$ describe this "binary mobility bias" as a key part of much diaspora and development policy, in which the assumption is that diasporas will naturally wish to contribute to the development of their homeland, and ideally eventually return to it. It is this rootedness in the homeplace - most commonly imagined at the nation-state scale - that is assumed to characterize all members of a given diaspora and to mobilize their action for 'development'. There have been lively debates over many years between those who have emphasized the cosmopolitan character of global diasporas as opposed to those who argue for the universal significance of belonging in a specific place even in an era of global convergence (see for example Kibreab 1999 and the subsequent responses) but when these are translated into the policy arena the idea of 'home' becomes far more instrumental and less nuanced. The point here is not so much about the real and evolving meaning of place in people's lives as the means of using sentiments to pursue quite practical political goals.

The fourth, and final conceptual area underpinning the development-diaspora field concerns the linked ideas of securitization and financialization. These are terms that have generally achieved far more prominence in development studies than in diaspora studies thus far (Bracking, 2016). In broad terms securitization is the process of placing increasing ideological and fiscal emphasis on perpetuating state stability by shifting more resources to forms of hard power (military spending, intelligence services) and soft power (diplomacy, deradicalization) in the face of a widespread sense of escalating risks (terrorism, climate change, financial volatility). Critics argue that the sense of risk is exaggerated in order to justify the reduction of civil liberties and the reorientation of limited public resources towards security. The 'securitization of development' entails not only efforts to manage or end violent conflicts in the 
Global South (which are seen as a barrier to development at the site of the conflict) but also to end conflicts that are seen to provide sites where global terrorist movements are thought to find sustenance (for example in Syria, Libya, Pakistan, Nigeria or Afghanistan). In a general sense committing to development in the Global South becomes recast as a strategy for reducing the risks of global insecurity by reducing the spaces where terror can flourish by reforming or replacing ineffective states (Duffield, 2005).

Financialization refers to the long history of the growing autonomy and power of finance capital in relation to industrial capital. In the development sector this initially meant an increased emphasis on financing development from the private sector by encouraging entrepreneurship as well as a growing use of financial instruments like micro-credit or property mortgages to achieve development goals. Following the Addis Ababa Agenda for Action (2015) the financialization of development has moved beyond this to involve much deeper engagement with hedge funds, investment banks, venture capitalists, sovereign wealth funds, and most particularly the big global accountancy firms, who often provide the 'kite mark' that reassures other financial actors. Their intent is to deliver development by creating new markets that open up novel ways of investing through creating new products. Government aid budgets are being used to enable this process of financialization. As Mawdsley $(2016,1)$ puts it "[f]oreign aid is being used to de-risk investment, 'escort' capital to 'frontier' markets, and carry out the mundane work of transforming objects into assets available to speculative capital flows." In short international development as a whole is being transformed simultaneously by securitization and financialization, but the significance for this specific discussion is that diasporas are relevant to both.

The diaspora-development field is connected to processes of securitization and finacialization because (a) mobile people in general and some diasporas in particular are seen as a significant security risk, and (b) diaspora remittances and diaspora investment represent one of the major sites for experiments in financialization.

One of the central ideas used to promulgate the idea of an ever present security risk in the West is a sense of the existence of hidden global networks used to enable terrorism. Since diasporas are, often, also global networks (though not really hidden ones) it only requires a short leap of the imagination to cast suspicion on them. As Mark Duffield puts it when reflecting on this interweaving of development and security: "the new global danger no longer necessarily lies with the abject poor, who are fixed in their misery: instead, it pulses from those mobile subpopulations capable of bridging and circulating between the dichotomies of North/South; modern/traditional; and national/international." $(2005,13)$.

In this context the job of development becomes not just to control 'failed states' but also to engage with these mobile sub-populations. So for example, in the aftermath of the 2001 terrorist attacks on the USA, the FBI intensified their preexisting enquiry into al-Barakaat's links with al-Qaeda and its leadership. AlBarakaat was a money transfer company that primarily served the Somali 
diaspora and operated mainly in the US, UAE, Kenya and Somalia. Though ultimately the FBI were unable to prove any illegal connections and closed the enquiry in 2002, retail banks in the US and elsewhere started to withdraw services from money transfer companies. They feared major fines from the US government if links between the diaspora remittance companies and terrorist organisations were ever found. Whilst advocates for diasporas drew attention to the negative humanitarian consequences of closing down the remittance corridor (Lindley and Mosley, 2014) official development organizations struggled to reconcile the contradictions between the desire for security and the desire to reduce the number of failing states by capitalising on the flow of diaspora remittances. The development task became finding a way to maintain these flows of diaspora capital into Somalia, but in a secure, transparent, formal way (DFID. ) Meeting this goal illustrates how securitization and financialization are closely connected.

Remittances also form a key focus of financialization efforts addressed to the diaspora by the global development sector - the diaspora's money is being reimagined as an important source of development finance. As Kavita Datta puts it, the process is taking what was once an 'alternative' form of capital flow and 'mainstreaming' it (2017). The goal is to shift a greater proportion of moneytransfers into secure 'formal' routes (operated by trusted, regulated bodies such as specialist companies, banks, post-offices) and away from 'informal' (such as hand-carries, hawala or small corridor-specific operators). This process of making remittances 'safe' simultaneously opens up the possibility of new financial products derived from these capital flows now passing through formal banking channels. The most obvious such products are (confusingly) called securitizations. This is where different assets (often illiquid assets such as mortgages) are pooled together so as to provide a new product that which generates interest and can be sold to investors. In the diaspora case pooled future remittance receipts can be treated as an asset against which a bank can borrow money by selling a bond to investors. In some circumstances (for example where local risks make sovereign borrowing expensive) such products can enable banks in the developing world to raise funds at advantageous rates. Such experiments in development finance are not limited either to diaspora remittances or to securitizations (more direct 'diaspora bond' issues are also much discussed) but they are symptomatic of current debates. A financial discourse is in the ascendant among policy-makers in the development-diaspora field.

In this chapter we have shown how a series of governmental and nongovernmental actors have identified specific goals and roles in a process of steering diasporas towards contributing to international development. It has been argued that in a matter of a few decades the idea of diasporas being part of the development process has moved from the periphery to the mainstream, largely driven by an interest in remittances. The actors with the greatest interest and responsibility in this process are currently seen as the governments of diaspora homelands, who are increasingly expected to enrol their diasporas into a national development project. In this context the definition of 'diaspora' is highly instrumental - if an individual is willing to participate in the development of a country they call home, then they are a member of a diaspora. 
More critically we have set out four conceptual areas in this field where the encounter between diaspora and development can generate productive conceptual insights. First, a focus on diaspora reveals the illusion of the way modernity is located in development studies. Second, a focus on diaspora reveals the core historical role of colonies and the slave-trade in the production of the $21^{\text {st }}$ century spaces we call the Developed and the Developing World. Third, a focus on diaspora reveals the way that the idea of 'belonging' can be treated as an asset to be used by development policy-makers and simultaneously as a moral discourse to underpin a geographical ordering of who belongs where. Finally we suggest that a focus on diaspora brings broad claims about the securitization and financialization of development into sharp empirical focus. So in conclusion it seems that as the diaspora-development field has evolved, it has revealed much more about development than about diasporas. Perhaps the time is now right to reverse the question and to ask what forty years of experiments in development practice have taught us about the meaning and character of diasporas?

\section{REFERENCES}

Bakewell 02008 'Keeping them in their place': the ambivalent relationship between development and migration in Africa. Third World Quarterly 29, 7, 1341-1358

Bracking S., 2016, The Financialisation of Power: How Financiers Rule Africa. London: Routledge

Carney J 1993 Black rice: the African origins of rice cultivation in the Americas. Harvard University Press, Cambridge, MA

Datta K 2009 Transforming South-North relations? International migration and development. Geography Compass 3, 1, 108-134

Datta K 2017 'Mainstreaming' the 'alternative'? The financialization of transnational migrant remittances in Martin, R. and Pollard, J. Handbook on the Geographies of Money and Finance, Cheltenham: Edward Elgar p.539-561

Duffield, M. 2005 Human security: Linking development and security in an age of terror. in New Interfaces between Security and Development: Changing Concepts and Approaches, ed. S. Klingebiel, German Development Institute, Bonn.

Gamlen A, 2014 Diaspora Institutions and Diaspora Governance, International Migration Review, 48, S180-S217.

de Haas H 2007 Turning the tide? Why development will not stop migration. Development and Change 38, 5, 819-841

Kibreab, G (1999) Revisiting the debate on people, place, identity and displacement, Journal of Refugee Studies, 12(4) 384-410

Kleist, N and Turner, S. (2013) Agents of Change? Staging and Governing Diasporas and the African State, African studies, 72, 2, 192-206 
Levitt P and Lamba-Nieves D (2011), Social Remittances Revisited, Journal of Ethnic And Migration Studies 37(1) 1-22

Lopez, S (2015) , The Remittance Landscape: The Spaces of Migration in Rural Mexico and Urban USA, Chicago: University of Chicago Press

MacRae, M., and M. Wright (2006), "A Model Diaspora Network: the Origin and Evolution of Globalscot," in Diaspora Networks and International Migration of Skills, ed. Y. Kuznetsov (Washington: World Bank Institute).

Mawdsley, E (2017) Development geography II: Financialization, Progress in Human Geography, http://journals.sagepub.com/doi/abs/10.1177/0309132516678747

McGregor, JoAnn (2008) Children and 'African values': Zimbabwean professionals in Britain reconfiguring family life. Environment and Planning A, 40 (3). pp. 596-614.

Mercer, C Page B and Evans M (2008) Development and the African diaspora: place and the politics of home, London: Zed

Mithra, P (2016) Addition by Subtraction: How Diasporas Can Boost HomeCountry Growth, IMF Direct (blog) https://blogimfdirect.imf.org/2016/05/18/addition-by-subtraction-how-diasporas-canboost-home-country-growth/

Mohan, G. (2002) 'Diaspora and Development', in Robinson, J. (ed.)

Displacements and Development, Oxford University Press: Oxford pp77-139

Raghuram P 2009 Which migration, what development? Unsettling the edifice of migration and development. Population, Space and Place 15, 103-117

Ratha, D and Plaza, S., 2016, Migration and Development a role for the World Bank Group, http://pubdocs.worldbank.org/en/468881473870347506/Migration-andDevelopment-Report-Sept2016.pdf

Sinatti G and C Horst 2014 Migrants as agents of development: diaspora engagement discourse and practice in Europe. Ethnicities 15, 1, 134-152 